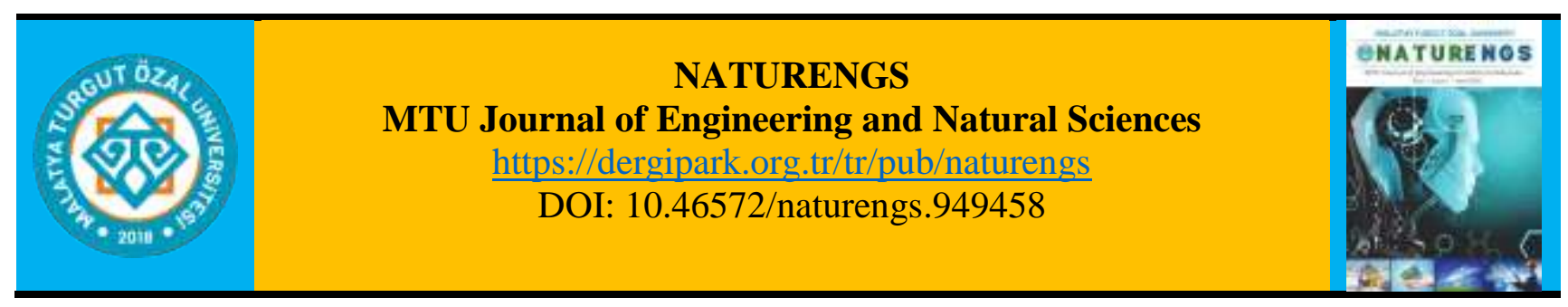

\title{
Effects of Different Nose Cone Designs on Trajectory and Impact Angle of Smart Fire Extinguishing Ammunition
}

\author{
Murat TOPTAŞ ${ }^{1^{*}}$, Mehmet YILMAZ ${ }^{2}$ \\ ${ }^{1}$ Department of Mechanical Engineering, Faculty of Engineering, Inonu University, Malatya, Turkey. \\ ${ }^{2}$ Department of Mechanical Engineering, Faculty of Engineering, Inonu University, Malatya, Turkey.
}

(Received: 08.06.2021; Accepted: 19.06.2021)

\begin{abstract}
A nose cone is the conically shaped tip part of a missile, bomb or aircraft, used to regulate the behavior of oncoming airflow and minimize drag. In this study, the effects of different nose cone designs on the trajectory and impact angle of smart fire extinguishing ammunition were investigated. For this purpose, three different types of ammunition with different nose cone profiles were designed: spherically blunted conic nose cone, spherically blunted tangent ogive nose cone and truncated tangent ogive nose cone. A virtual wind tunnel was created in the computer environment and CFD software was used to calculate the drag coefficients for each design. By applying Newton's second law of motion, the horizontal distance the ammunition received before the striking fire, impact speed, and impact angle were calculated. The obtained results were compared using One-Way ANOVA (analysis of variance) to determine whether there is statistical evidence that the associated population means are significantly different. It was determined that the three types of nose cone designs examined did not have a significant effect on the impact speed, impact angle and horizontal distance of the ammunition at the investigated speeds and altitudes. On the other hand, flame detection, distance measurement and impact sensors, which should be in the smart fire extinguishing ammunition, should be on the plane at the front of the ammunition and in contact with the external environment. To place these sensors in the nose cone, a truncated tangent ogive nose cone was chosen as the nose cone for the smart fire extinguishing ammunition.
\end{abstract}

Keywords: Aerial Fire Fighting, Smart Fire Extinguishing Ammunition, Nose Cone, CFD.

\section{INTRODUCTION}

Aircraft, or any type of body moving through a fluid, encounter a drag force that decreases their performance. The drag force is due to the combined effects of pressure and wall shear forces in the flow direction. The part of drag that is due directly to wall shear stress $\tau_{\omega}$ is called the skin friction drag (or just friction drag), and the part that is due directly to pressure $P$ is called the pressure drag [1]. Pressure drags occurs by resultant pressure distribution over the surface [2]. Layer separation occurs when the flow slows down and static pressure increases in the direction of flow [3]. This situation is also known as adverse pressure gradient [4]. Adverse pressure gradients produce pressure drags. To improve performance, designers working in this area should identify where these resistance forces are dominant and eliminate or minimize them.

The most important parts of a body exposed to these influences as it passes through a fluid are nose cones. A nose cone is the conically shaped tip part of a missile, bomb or aircraft, used to 
regulate the behavior of oncoming airflow and minimize drag. Nose cone profiles have a significant impact on aerodynamic characteristics [5]. Because they are the first parts that meet the resistance forces, arising from pressure and friction drags. Nose cones serve to regulate the behavior of the oncoming airflow and minimize drag. However, at velocities below $0.8 \mathrm{Mach}$, the pressure drag for all kinds of the nose cone is zero and the main resistance factor is the friction drag [6]. To reduce the drag forces and increase the performance of the design, the most appropriate nose cone type should be chosen. Conic, spherically blunted conic, bi-conic, tangent ogive, spherically blunted tangent ogive, secant ogive, elliptic, parabolic, power series and Haack series are the cone designs generally used for aerospace applications [6].

Smart fire extinguishing ammunition (SFEA) is a new and effective product we have designed for use in aerial firefighting (Figure 1a). This product was called smart fire extinguishing ammunition, taking into account some electronic equipment and software that makes the product autonomous. To realize the design goals and requirements, and also to ensure the practicality and cheapness of its use, the ammunition was designed with the dimensions of MK82 air-to-ground general-purpose NATO ammunition (Figure 1b). There is a boron-based extinguishing agent in the ammunition and the ammunition is thrown onto the fires from an air vehicle. The explosive placed in the ammunition center detonates when it reaches the fire area and the extinguishing agent is scattered over the fire area.

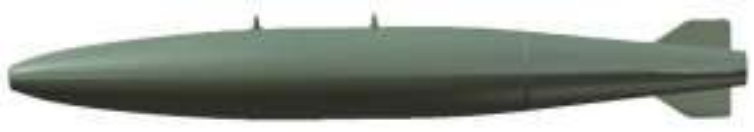

(a)

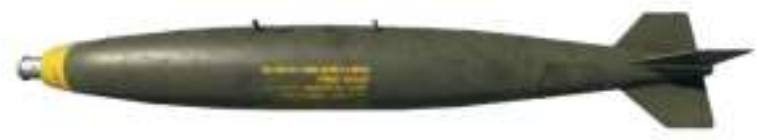

(b)

Figure 1. (a) Smart fire extinguishing ammunition (SFEA) (b) Low drag general-purpose bomb Mark-82

SEFA is expected to do its job successfully regardless of the type of fire. For this to happen, the spread of the extinguishing agent on the fire must occur in different patterns. One way to achieve this result is to drop the ammunition on the fire at different angles. Figures 2 and 3 show what the angles of impact of SFEA should be for different types of fires and what the dispersion of the extinguishing agent should be.
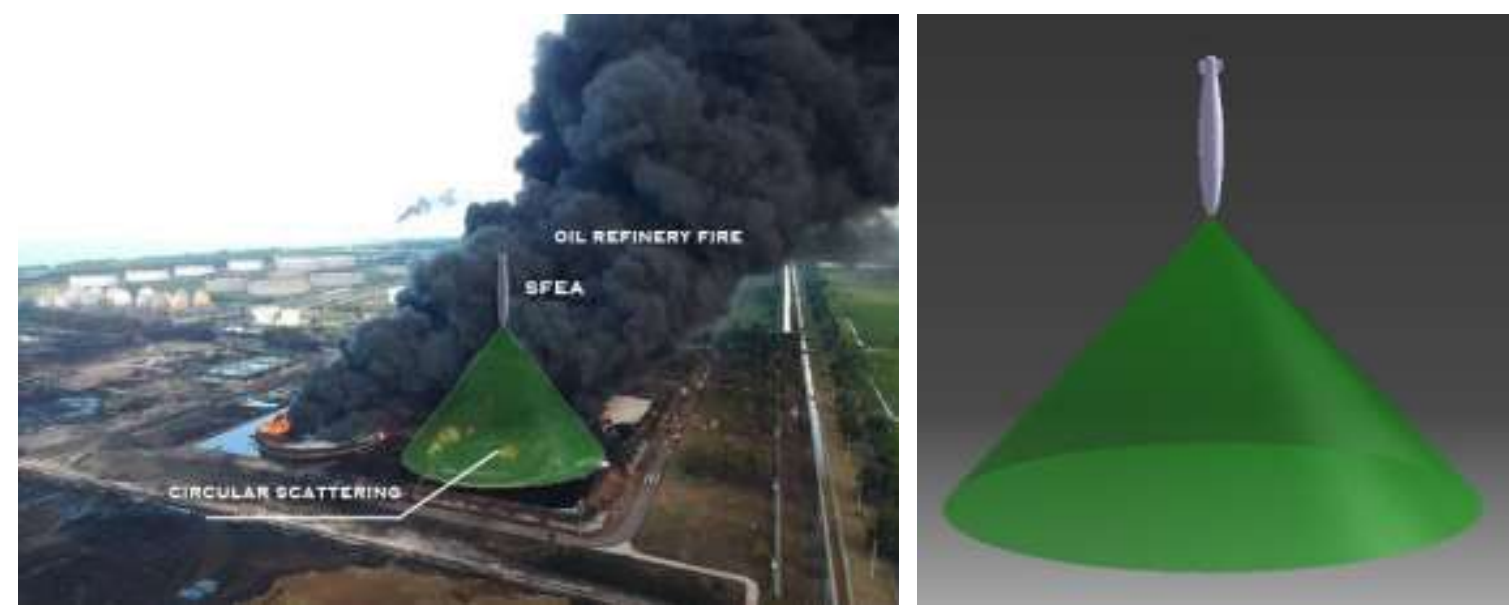

Figure 2. Circular scattering template of SFEA 

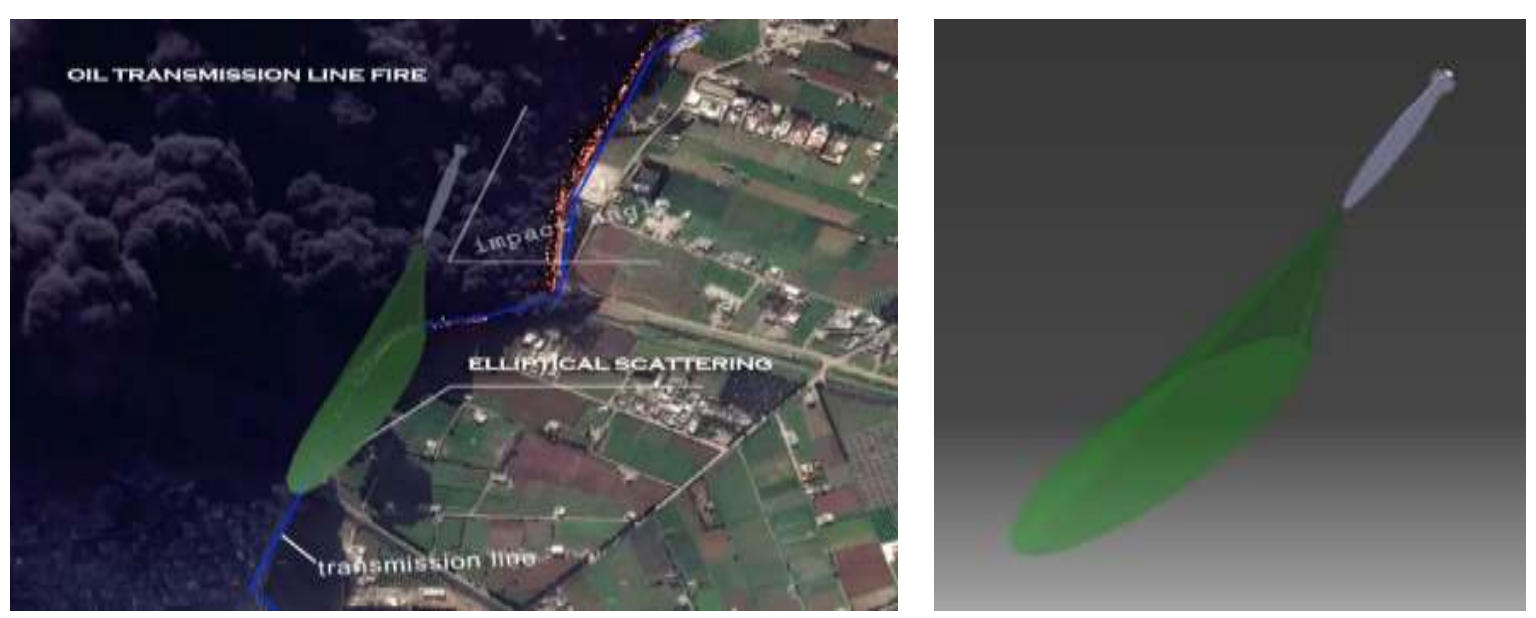

Figure 3. Elliptical scattering template of SFEA

This study aims to determine the most appropriate type of nose cone for SFEA and to examine the effects of different nose cone designs on the trajectory and impact angle of SFEA. For this purpose, three different types of ammunition with different nose cone profiles were designed: spherically blunted conic nose cone, spherically blunted tangent ogive nose cone and truncated tangent ogive nose cone. A virtual wind tunnel was created in the computer environment and Ansys Fluent 16.0 was used to calculate the drag coefficients for each design. By applying Newton's second law of motion, the horizontal distance the ammunition received before the striking fire, impact speed, and impact angle were calculated. The obtained results were compared using One-Way ANOVA (analysis of variance) to determine whether there is statistical evidence that the associated population means are significantly different. As a result of the study, the most appropriate type of nose cone for SFEA was determined.

\section{SMART FIRE EXTINGUISHING AMMUNITION (SFEA)}

Aerial firefighting methods are complementary to land firefighting methods. In aerial firefighting methods, extinguishing agents such as water, foam and soil are left on fires by an air vehicle. However, because of the air resistance and also airflows caused by the heated air, the appropriate amount of extinguishing material can not reach its target. Therefore, an innovative and effective product, which can be used in aerial firefighting, has been designed. This product was called smart fire extinguishing ammunition (SFEA), taking into account several electronic equipment and software that make the product autonomous. SFEA is an effective product that has not been designed before. To realize the design goals and requirements, and also to ensure the practicality and cheapness of its use, the ammunition was designed with the dimensions of MK-82 air-to-ground general-purpose NATO ammunition (Figure 4). In this way, it will be possible to load the SFEA without the need for any change on the aircraft which will carry ammunition. This means that no extra infrastructure investment costs will arise for the countries that will purchase the SFEA. The target of the SFEA is open area fires such as forests, petrochemical plants, oil and gas transmission lines and ammunition depots outside of residential areas. The purpose of SFEA is to deliver the extinguishing agent in the ammunition to the fire point with minimum deviation without being affected by weather conditions. Having the appropriate sensors, electronic equipment and software, the SFEA can determine the most suitable point where the explosion will occur after the ammunition is dropped from the aircraft. 
The SFEA consists of ammunition body, nose cone, tail-wing assembly, extinguishing - cooling material, explosive substance, fuze, electronic equipment and software. Figure 5 shows the components of the smart fire extinguishing ammunition.

The SFEA is a new product for both the fire-fighting industry and the aviation industry. If the product goes into mass production, a combat tool that will make significant contributions in fighting fires will be obtained. Extinguisher-coolant can be left on the fire in the correct amount so that while the fires are extinguished, there will be no damage to the environment due to the use of excessive chemicals. In addition, considering both the efficiency of the product and the speed factors of the aircraft, fires can be controlled without spreading over large areas as before.

To design and create the three-dimensional product, computer-aided design software (Catia V.5) was used. Structural, flow and explosion analyses of the product were performed with ANSYS software. The software of the product was written in the $\mathrm{C}$ programming language.
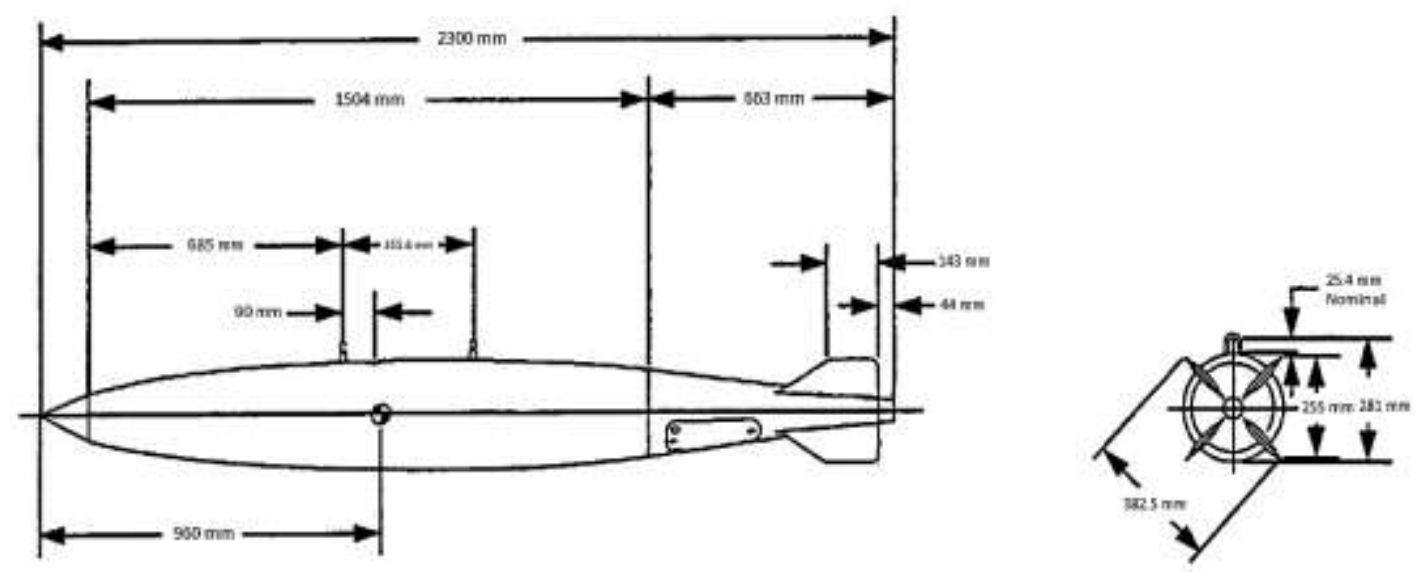

Figure 4. Dimensions of MK-82 ammunition [7]
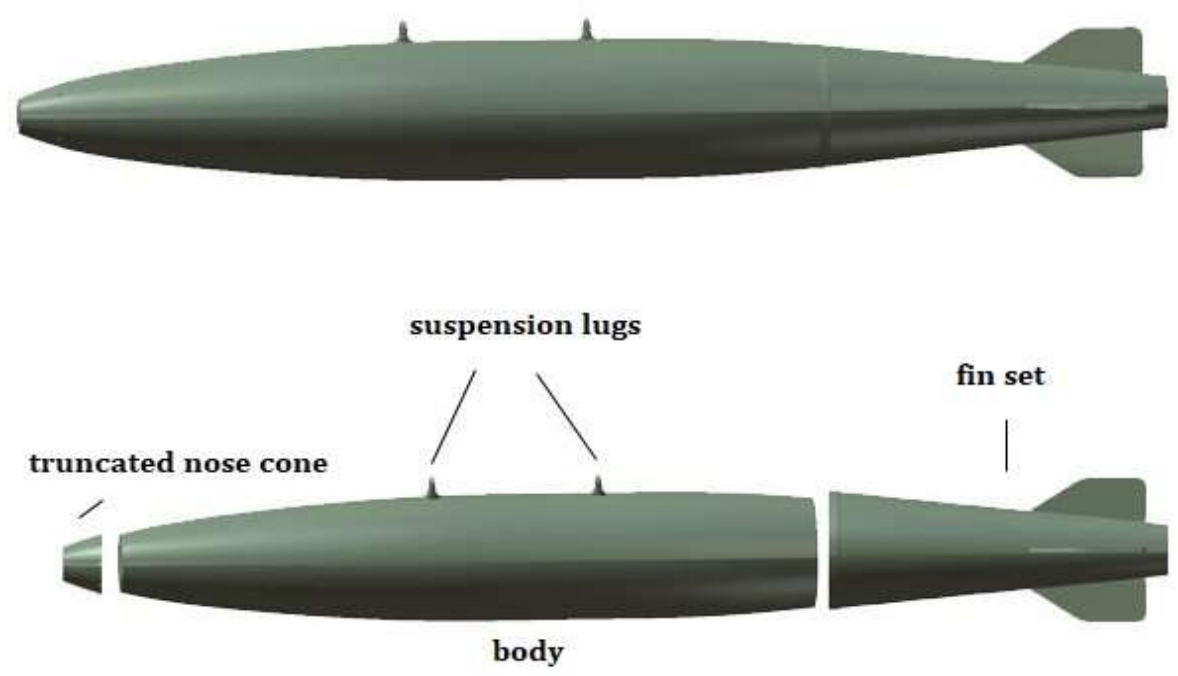

Figure 5. The smart fire extinguishing ammunition (SFEA) 


\section{MATERIAL AND METHODS}

\subsection{Design of Nose Cones}

Various types of nose cones and their aerodynamics performances have been investigated in the literature $[5,6,12]$. Three nose cone types have been selected and designed to suit the ammunition so that the SFEA will achieve the expected objectives and create a low drag coefficient. The nose cones examined are spherically blunted conic, spherically blunted tangent ogive and truncated tangent ogive type nose cones (Figure 6).

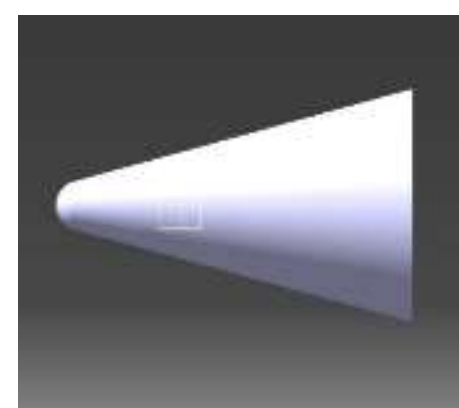

(a

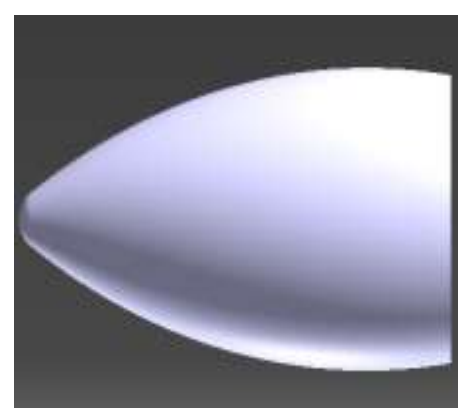

(b)

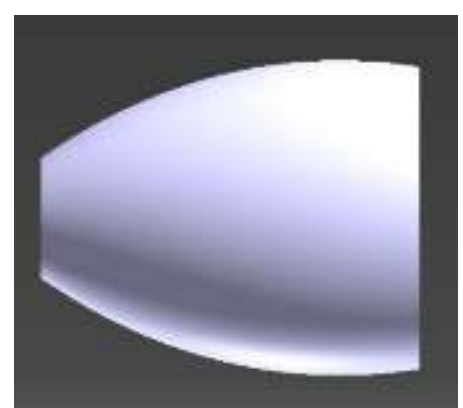

(c)

Figure 6. Types of nose cones studied: (a) Spherically blunted conic nose cone;

(b) Spherically blunted tangent ogive nose; (c) Truncated tangent ogive nose cone

Spherically blunted conic nose cones are created by blunting conic cones with a sphere (Figure 7-8). The point where the sphere meets the cone (tangent point) can be found from the following equations [7]:

$x_{t}=\frac{L^{2}}{R} \sqrt{\frac{r_{n}^{2}}{R^{2}+L^{2}}}$

$y_{t}=\frac{x_{t} R}{L}$

here " $L$ " is the total length of the nose cone, $R$ is the radius of the base, $r_{n}$ is radius of sphere which used for blunting. The center point $\left(\mathrm{x}_{0}\right)$ and apex point $\left(\mathrm{x}_{\mathrm{a}}\right)$ of the blunting sphere can be found using Eqs. (3) and (4), respectively:

$x_{0}=x_{t}+\sqrt{r_{n}^{2}-y_{t}^{2}}$

$x_{a}=x_{0}-r_{n}$

The second type of nose cone examined is the spherically blunted tangent ogive nose cone (Figure 9-10). Tangent ogive shape profiles are created by a segment of a circle tangent to the curve of the nose cone at the base of the missile, bomb, or aircraft. If this nose cone profile is blunted by capping it with a segment of a sphere, the point where the sphere meets the cone (tangent point) (Figure 10) can be found from the following equations:

$\rho=\frac{R^{2}+L^{2}}{2 R}$

$y=\sqrt{\rho^{2}-(L-x)^{2}}+R-\rho$

$x_{0}=L-\sqrt{\left(\rho-r_{n}\right)^{2}-(\rho-r)^{2}}$ 


$$
\begin{aligned}
& y_{t}=\frac{r_{n}(\rho-R)}{\rho-r_{n}} \\
& x_{t}=x_{0}-\sqrt{r_{n}^{2}-y_{t}^{2}}
\end{aligned}
$$

The apex point can be found using the same equation for the spherically blunted conic nose cone:

$$
x_{a}=x_{0}-r_{n}
$$

The third type of nose cone examined is the truncated tangent ogive nose cone (Figures 11 and 12). This type of nose cone is the same as the spherically blunted tangent ogive nose cone, except that the nose part is not spherically blunted, but is truncated directly after a certain length (Figure 12). The design equations for the truncated tangent ogive nose cone are the same as for the spherically blunted conic nose cone, except that the truncated tangent ogive nose cones are cut at a distance $\mathrm{x}_{\mathrm{a}}$ from the tip and are not blunted by any geometric shape (Figure 12).
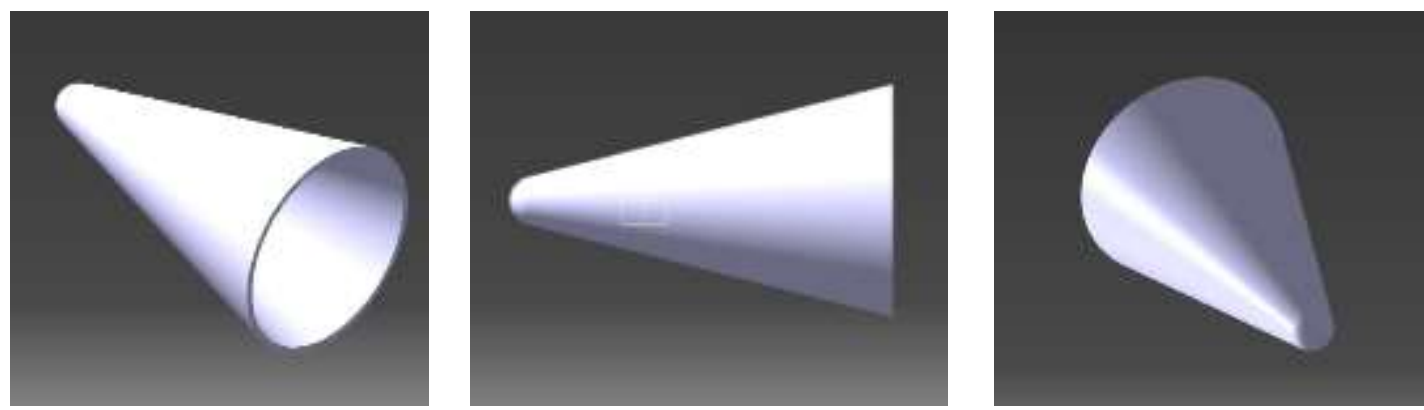

Figure 7. Spherically blunted conic nose cone

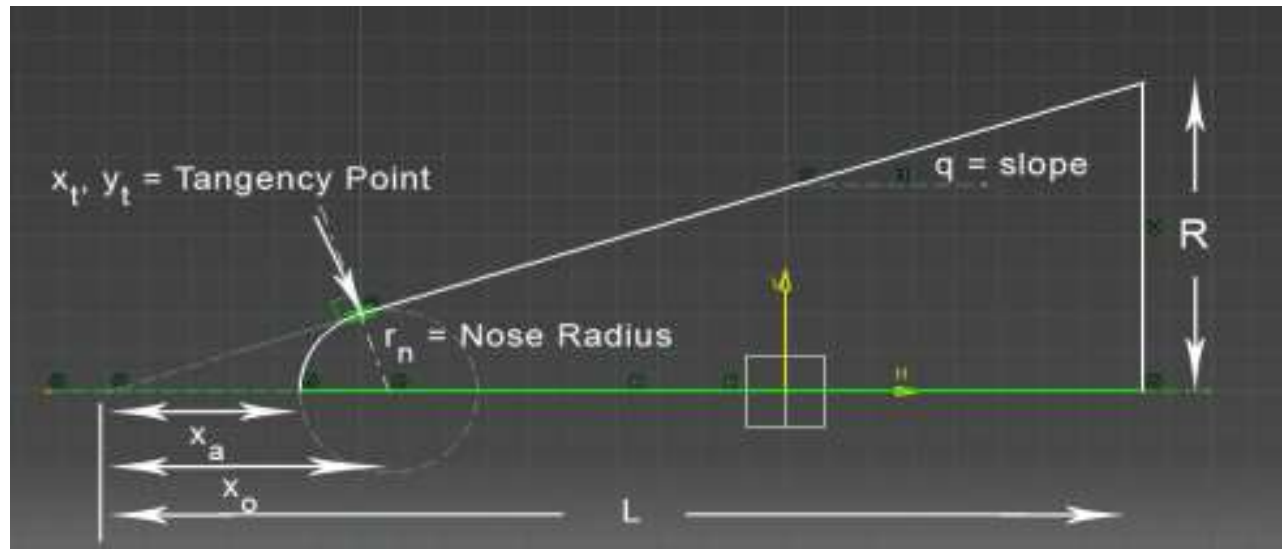

Figure 8. Spherically blunted conic nose cone profile [8]
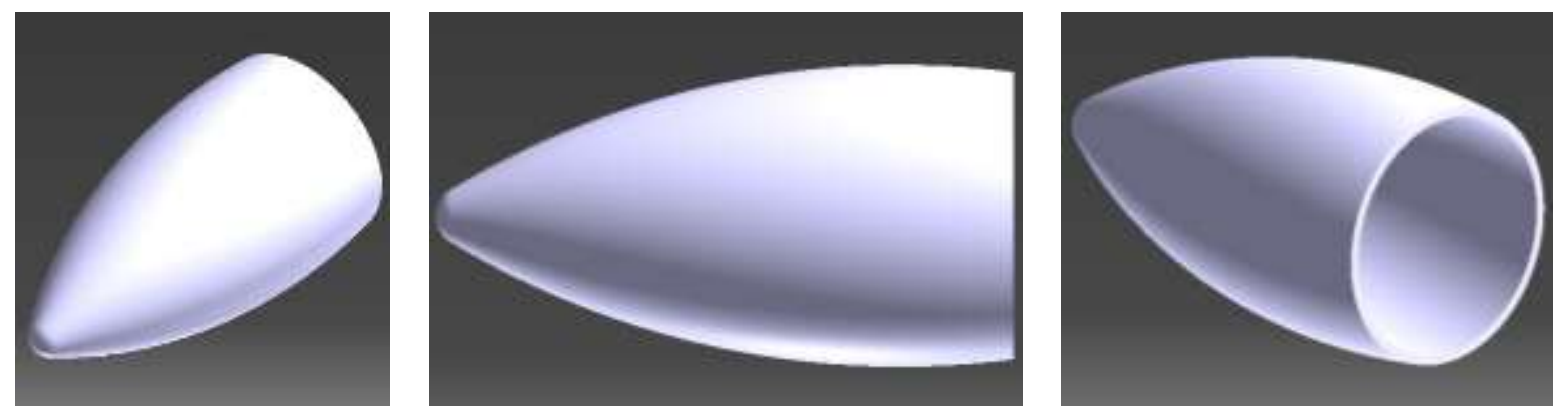

Figure 9. The spherically blunted tangent ogive nose cone 


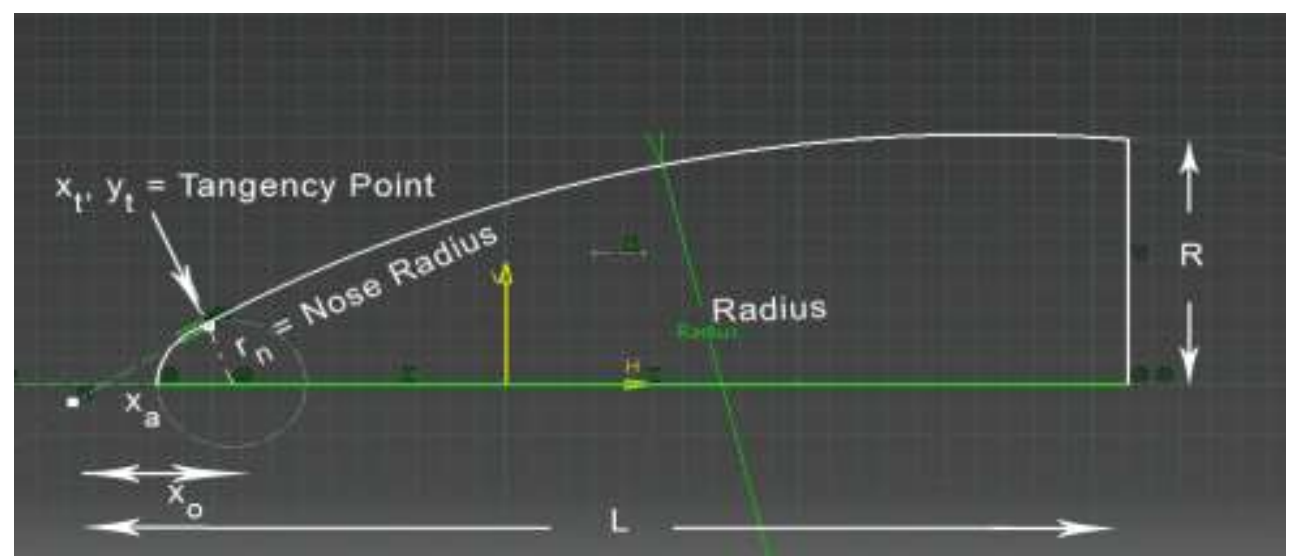

Figure 10. Spherically blunted tangent ogive nose cone profile [8]
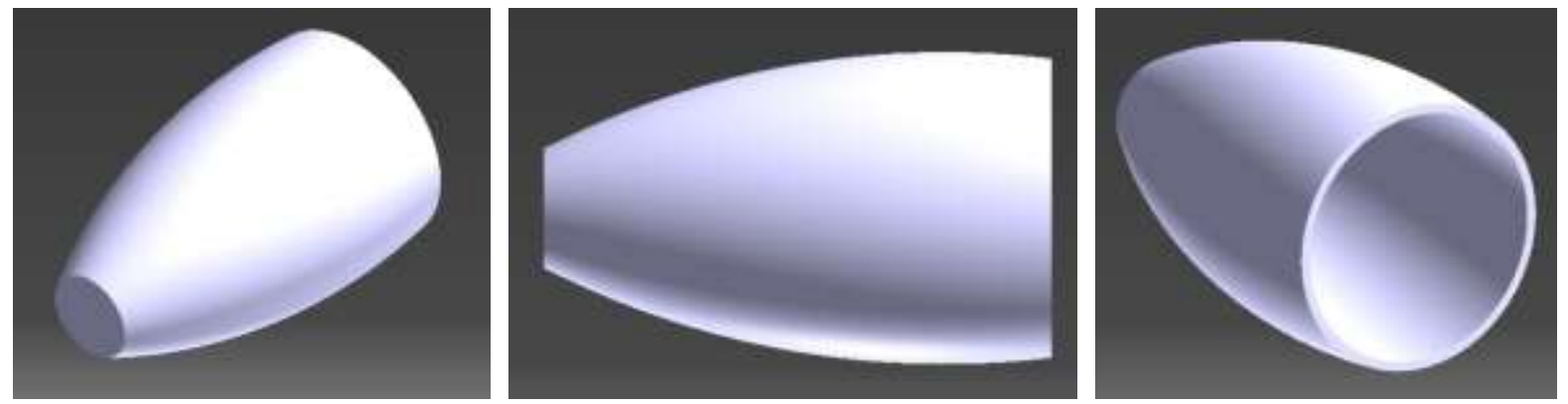

Figure 11. The truncated tangent ogive nose cone

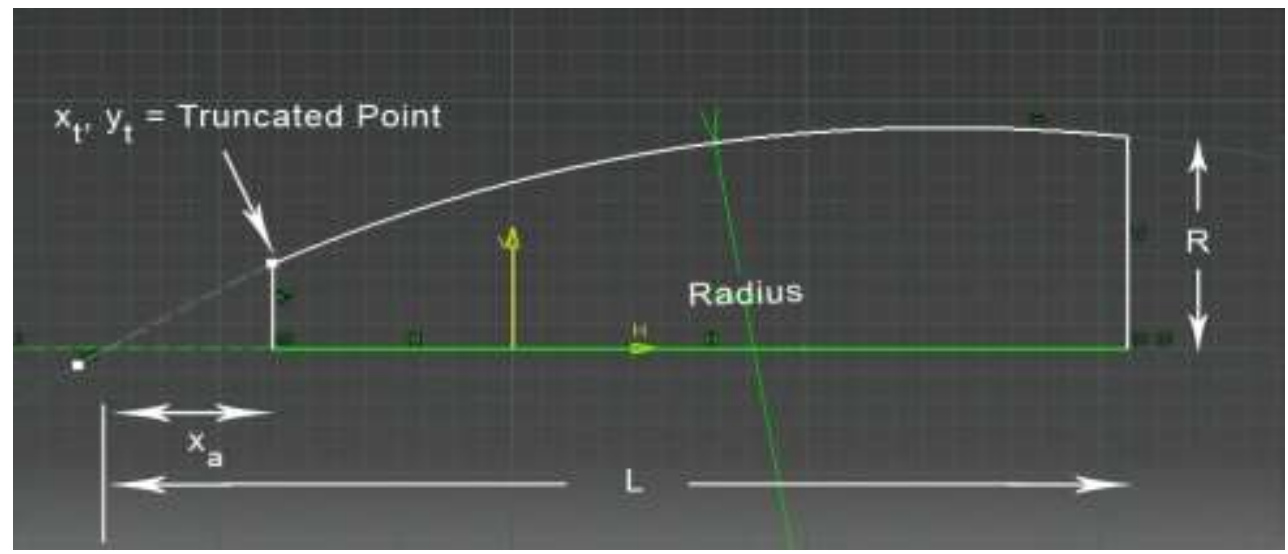

Figure 12. The truncated tangent ogive nose cone profile [8]

\subsection{Creating Solid Models of Nose Cones}

To realize the design goals and requirements, three suitable nose cone types were selected from the literature and modeled for the ammunition. Using Eqs. (1)-(10), the $\mathrm{x}$ and $\mathrm{y}$ coordinates for each nose cone were determined. Then, these coordinates were transferred to a $3 \mathrm{D}$ design software (Catia V5.R.20) and solid models of the objects were created. This solid model of nose cones was mounted to the body of SFEA. These models are given in Fig. 13. 


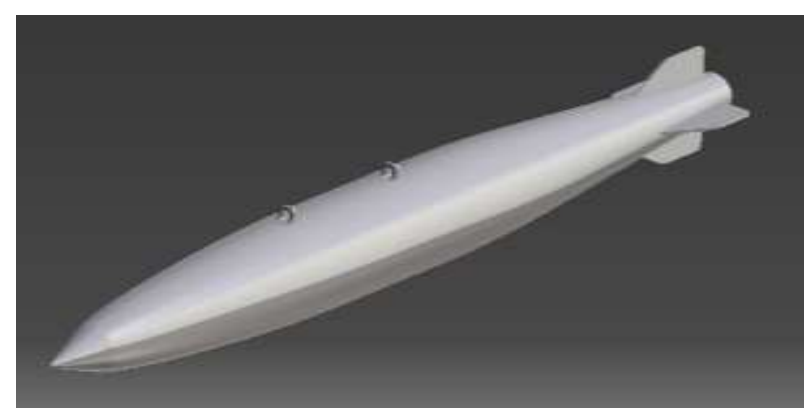

(a)

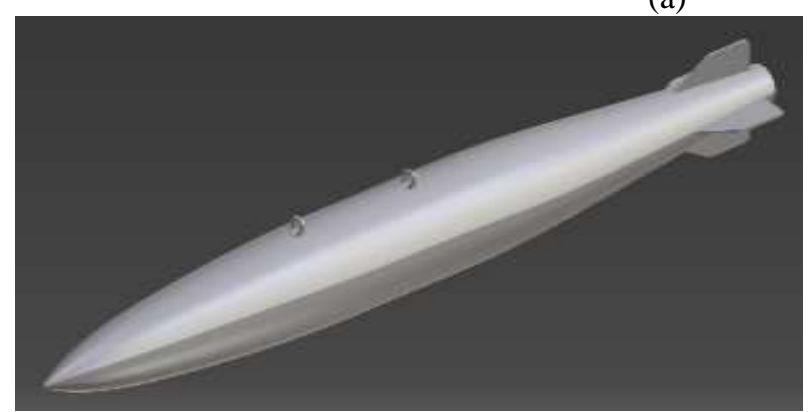

(b)

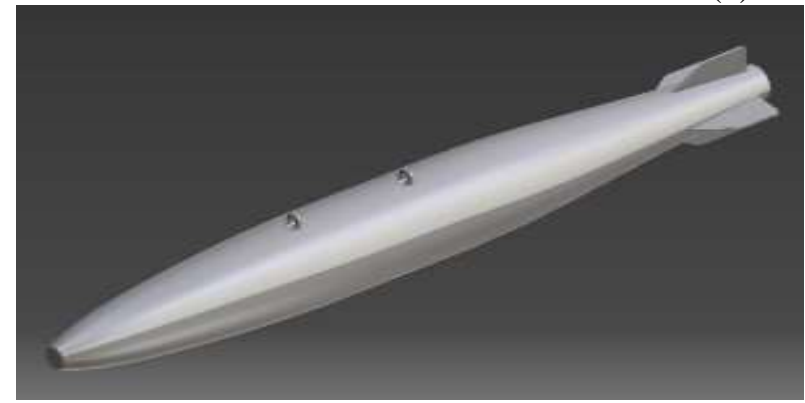

(c)
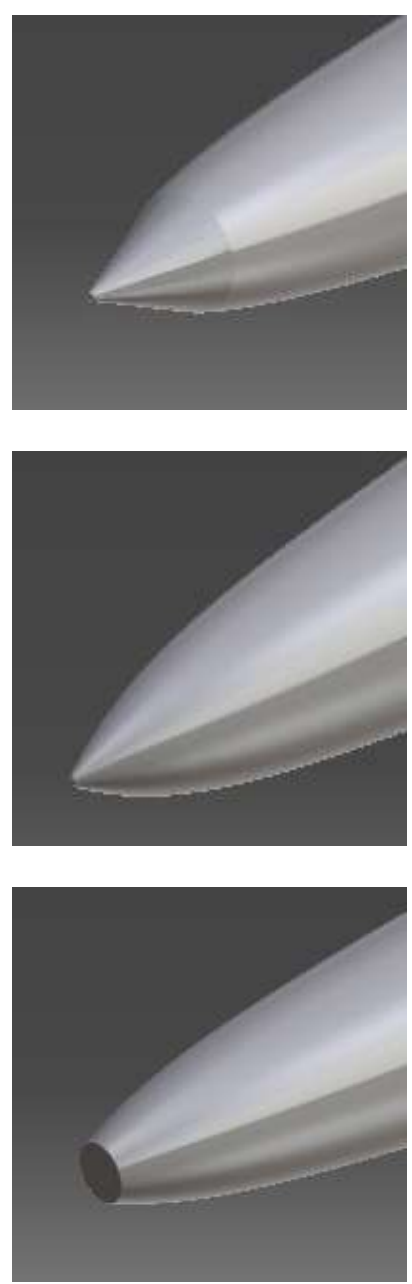

Figure 13. Different nose cones assemblies on ammunition body: (a) Spherically blunted conic nose cone; (b) Spherically blunted tangent ogive nose; (c) Truncated tangent ogive nose cone

\subsection{Creating The Mesh Structures}

The generated mesh structures and inflation layers associated with the ammunition geometries are shown in Figure 14.

\subsection{Ammunition Trajectory and Impact Angle Calculations}

The motion and path of the SFEA dropped from the aircraft can be described by Newton's second law of motion. If the trajectory of the SFEA dropped from the aircraft under the effect of drag force is expressed by force equations, the following equations are obtained. Here, the direction of the ammunition is taken as " $+\mathrm{x}$ " and the direction of fall (direction of gravity) is taken as "-y":

$$
\begin{aligned}
& F_{x}=m a_{x}=-m\left(\frac{V_{x}}{V}\right) b V^{2} \\
& F_{y}=m a_{y}=-m g+m\left(\frac{V_{y}}{V}\right) b V^{2} \\
& b=C_{d} \rho_{a} A / m
\end{aligned}
$$


b: air resistance $\left(\mathrm{m}^{-1}\right)$

$\mathrm{m}$ : mass of ammunition

$\rho_{\text {air: }}$ density of air $\left(\mathrm{kg} / \mathrm{m}^{3}\right)$

A: cross-sectional area of ammunition $\left(\mathrm{m}^{2}\right)$

$\mathrm{C}_{\mathrm{d}}$ : drag coefficient

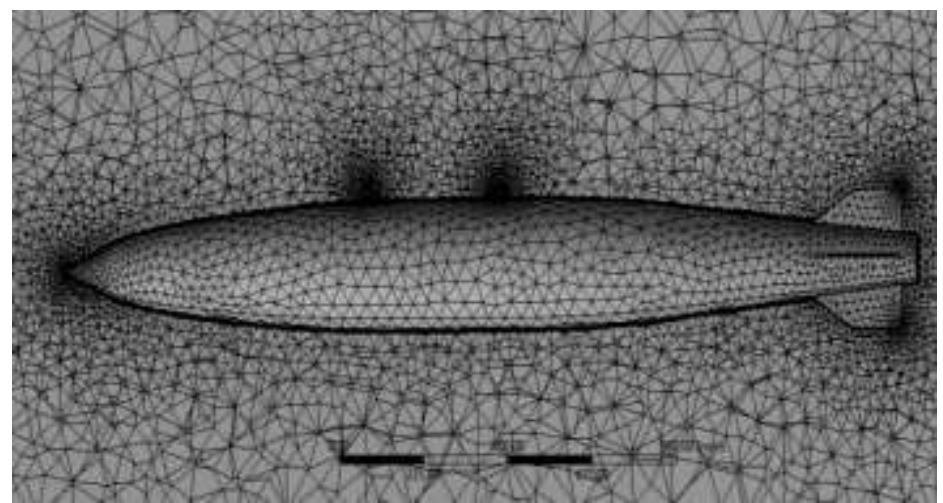

(a)

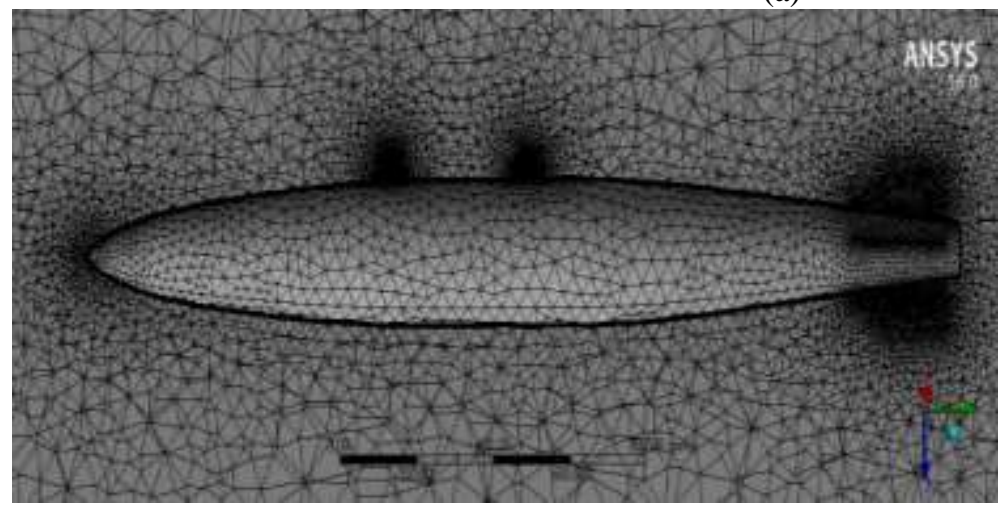

(b)

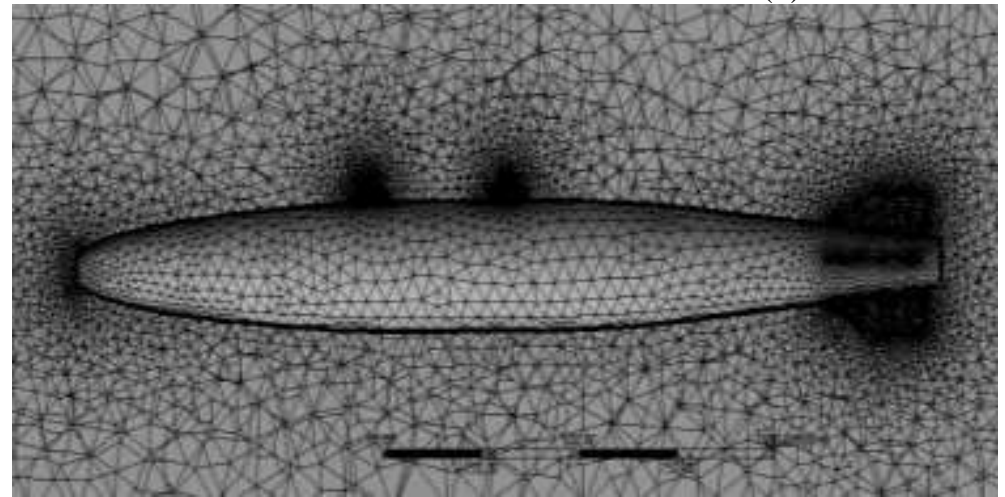

(c)
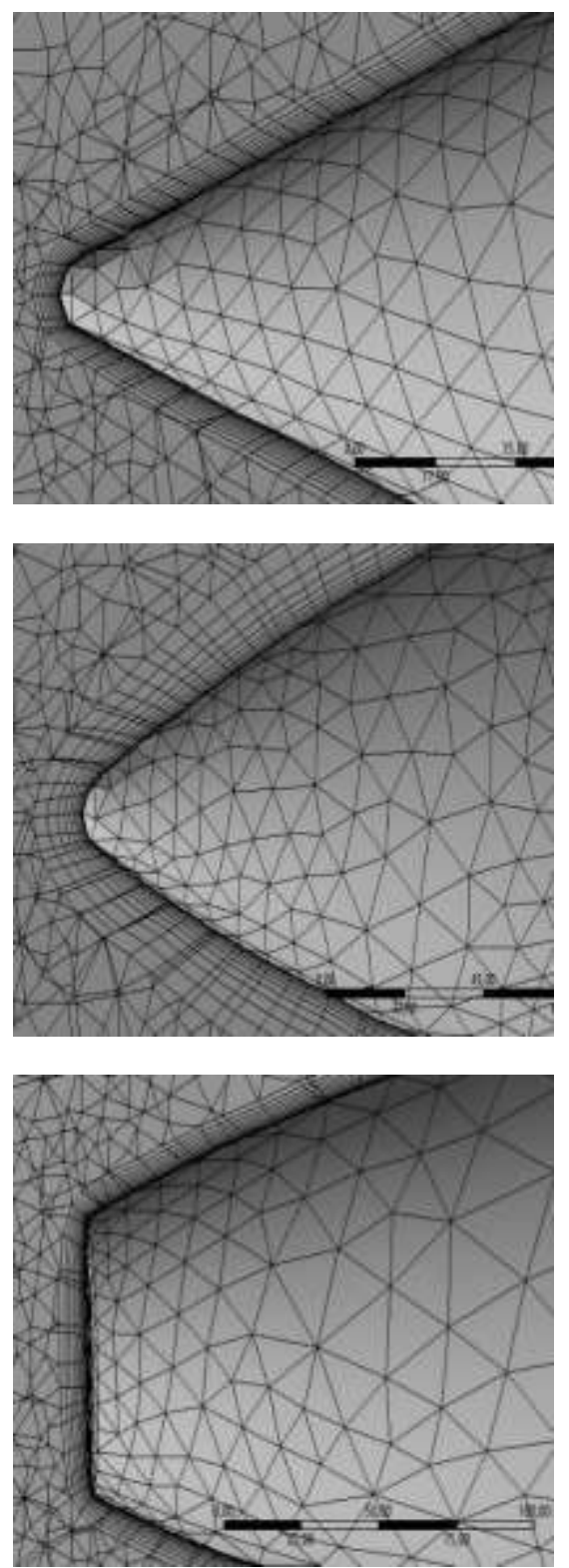

Figure 14. Mesh structures and inflation layers of nose cones: (a) Spherically blunted conic nose cone; (b) Spherically blunted tangent ogive nose; (c) Truncated tangent ogive nose cone

If Eqs. (11) and Eq. (12) are divided by mass, substituting $\mathrm{dV}_{\mathrm{x}} / \mathrm{dt}$ for $\mathrm{ax}, \mathrm{dV} / \mathrm{dt}$ for ay, and $\Delta \mathrm{t}$ for $\mathrm{dt}$, the following equations are obtained:

$V_{x}(t+\Delta t)=V_{x}(t)-b V_{x} V \Delta t$
$V_{y}(t+\Delta t)=V_{y}(t)-g \Delta t-b V_{y} V \Delta t$

When equations (14) and (15) are entered into a spreadsheet, $\mathrm{V}_{\mathrm{x}}, \mathrm{V}_{\mathrm{y}}$ velocities, a path taken by the ammunition in the $\mathrm{x}$-direction, and total travel time can be calculated for different heights 
(h) and drag coefficients $\left(\mathrm{C}_{\mathrm{d}}\right)$. Using the obtained velocities $\mathrm{V}_{\mathrm{x}}$ and $\mathrm{V}_{\mathrm{y}}$, the impact angle $(\theta)$ is calculated by the following equation:

$\theta=\tan ^{-1}\left(V_{y} / V_{x}\right)$

\subsection{Extinguishing Agent Release Rate Calculation}

The velocity vector on the third axis also should be known to determine the distribution of the extinguishing material with the explosion of the ammunition at the appropriate altitude. For this purpose, the Gurney equation was used, which gives the shrapnel speed resulting from the explosion of cylindrical-shaped ammunition. The Gurney equation for cylindrical ammunition [10]:

$V \sqrt{2 E}=\left[\left(M / C_{e x p}\right)+1 / 2\right]^{-0.5}$

$\mathrm{V}$ : Initial fragment velocity $(\mathrm{m} / \mathrm{s})$

$\sqrt{2 E}$ : Gurney constant for a given explosive

M: Mass of the fragment $(\mathrm{kg})$

$\mathrm{C}_{\text {exp: }}$ Explosive charge mass $(\mathrm{kg})$

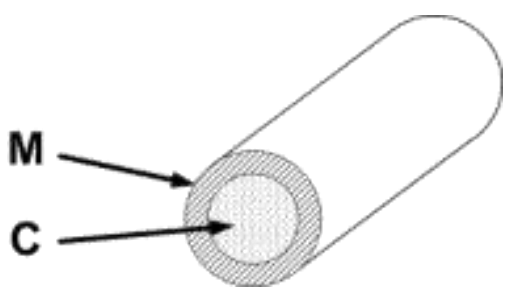

$\sqrt{ } 2 \mathrm{E}$ value is generally very close to $1 / 3$ of the detonation speed of explosives (Table 1 ). However, it is necessary to look at the relative effect factor (R.E.) of the explosive for the exact value. The relative effect factor is the ratio of the energy value of the same amount of explosives to the energy value of the TNT. Dynamite was used as an explosive in the SFEA. According to this:

$R . E .=\frac{E_{\text {dynamite }}}{E_{T N T}}$

Table 1. Gurney constants of some explosives [11]

\begin{tabular}{|c|c|c|c|}
\hline Explosive & $\begin{array}{c}\text { Density } \\
\left(\mathbf{k g} / \mathbf{m}^{\mathbf{3}}\right)\end{array}$ & $\begin{array}{c}\text { Detonation Velocity } \\
(\mathbf{m} / \mathbf{s})\end{array}$ & $\begin{array}{c}\text { Gurney Constant } \sqrt{2 E} \\
(\mathbf{m} / \mathbf{s})\end{array}$ \\
\hline Octol 75/25 & 1.81 & 8640 & 2896 \\
\hline PETN & 1.78 & 8260 & 2926 \\
\hline RDX & 1.81 & 8700 & 2926 \\
\hline RDX/TNT 60/40 (Cyclotol) & 1.68 & 7800 & 2402 \\
\hline Tetryl & 1.71 & 7570 & 2499 \\
\hline TNT & 1.61 & 6900 & 2438 \\
\hline Tritonal & 1.70 & 5480 & 2316 \\
\hline
\end{tabular}

\section{RESULTS AND DISCUSSION}

Drag coefficients were calculated for each nose cone type by performing flow analysis. Using the obtained drag coefficients, impact speed and impact angle calculations were made for the ammunition dropped with different speeds, jettison angles and altitudes.

\subsection{Analysis Parameters}

Flow analysis was performed by transferring the mesh structures to the Ansys Fluent environment and the drag coefficients for each model were numerically analyzed. Flow analysis was made according to the values in Table 2 . 
Table 2. Analysis parameters

\begin{tabular}{|c|c|}
\hline Input Parameters & Value \\
\hline Air Velocity $(\mathrm{m} / \mathrm{s})$ & 86 \\
\hline Air Density $\left(\mathrm{kg} / \mathrm{m}^{3}\right)$ & 1.205 \\
\hline Air Dynamic Viscosity $(\mathrm{kg} / \mathrm{m} . \mathrm{s})$ & $1.82 \times 10^{-5}$ \\
\hline Ammunition Length $(\mathrm{m})$ & 2.3 \\
\hline Flow Type & Incompressible \\
\hline Turbulence Model & SST k- $\omega$ \\
\hline Mach sayıs1 & 0.25 \\
\hline
\end{tabular}

\subsection{Drag Coefficients}

As a result of the CFD analysis performed in the Ansys Fluent environment, the drag coefficients for each type of the three nose cones were calculated. The drag coefficients for each nose cone are given in Figure 15 and Table 8. The drag coefficient was found to be 0.136 for the spherically blunted conic nose cone, 0.138 for the spherically blunted tangent ogive nose cone, and 0.154 for the truncated tangent ogive nose cone. As can be seen, the drag coefficients for the spherically blunted conic nose cone and the spherically blunted tangent ogive nose cone are very close to each other, while the drag coefficient for the truncated tangent ogive nose cone is slightly higher $(+11.76 \%)$. The higher coefficient of drag in the truncated tangential ogive nose cone is due to the deterioration of the flow structure and the formation of a separation zone. This causes the pressure drag to increase.

Table 8. Drag coefficients for a different type of nose cones

\begin{tabular}{|c|c|}
\hline Nose Cone Type & Drag Coefficient \\
\hline Spherically Blunted Conic & 0.136 \\
\hline Spherically Blunted Tangent Ogive & 0.138 \\
\hline Truncated Tangent Ogive & 0.152 \\
\hline
\end{tabular}

\subsection{Ammunition Trajectory and Impact Angle}

With the drag coefficients obtained, impact speed and impact angle calculations were made for ammunitions dropped from different speeds, jettison angles and altitudes. Ammunition trajectory and impact angle for spherically blunted conic nose cone are given in Table 3, ammunition trajectory and impact angle of spherically blunted tangent ogive nose cone in Table 4 , and ammunition trajectory and impact angle of truncated tangent ogive nose cone in Table 5.

The one-way analysis of variance (ANOVA) was performed on the results using Minitab software to numerically show the effect of different nose cone designs on the impact angle and impact speed. Table 6 shows the results of a one-way analysis of variance for the impact angle versus nose cone type. In Table 7, the results of a one-way analysis of variance for the impact speed versus nose cone type are given. Since the p-values were greater than 0.05 in the ANOVA analysis, the nose cone difference did not have any effect on the impact angle and impact speed. On the other hand, flame detection, distance measurement and impact sensors, which should be in the smart fire extinguishing ammunition, should be on the plane at the front of the ammunition and in contact with the external environment. To place these sensors in the nose 
cone, a truncated tangent ogive nose cone was chosen as the nose cone for the smart fire extinguishing ammunition.

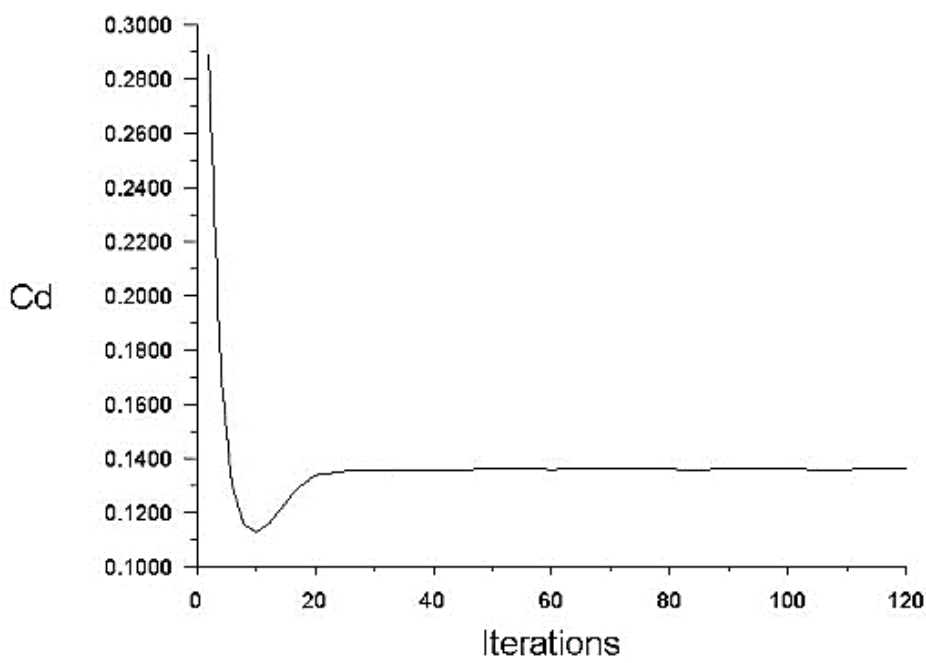

(a)

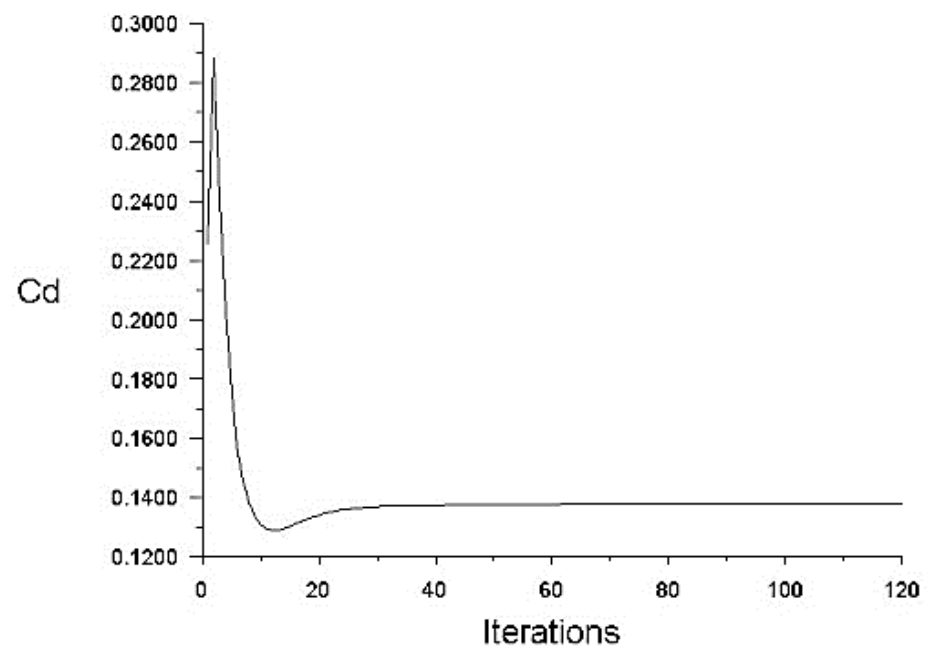

(b)

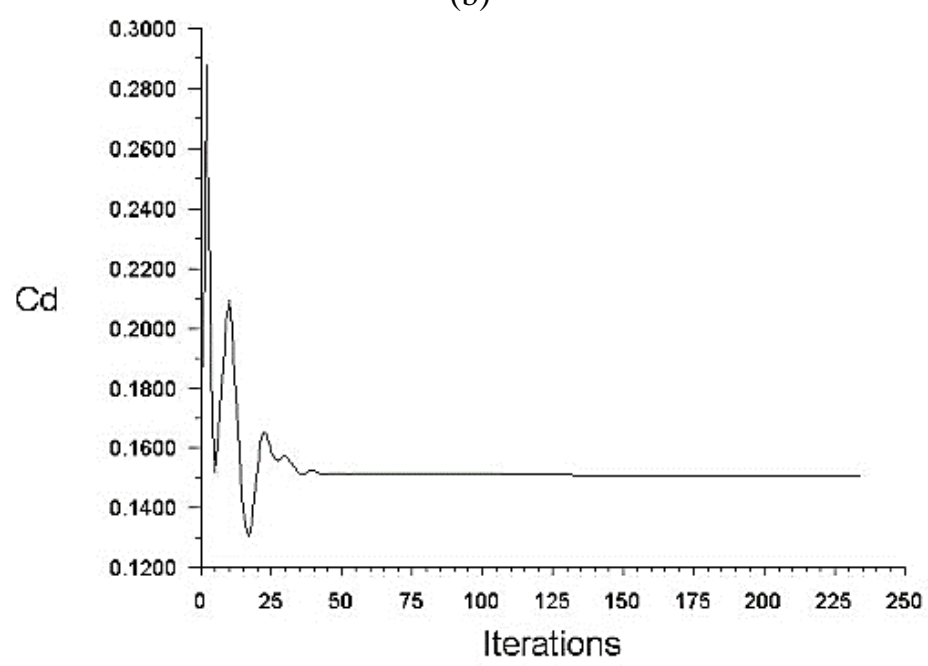

(c)

Figure 15. Nose cone drag coefficients: (a) Spherically blunted conic nose cone; (b) Spherically blunted tangent ogive nose; (c) Truncated tangent ogive nose cone 
Table 3. Trajectory and impact angle for the ammunition with spherically blunted conic nose cone

\begin{tabular}{cccccc}
\hline \hline $\begin{array}{c}\text { Aircraft Speed } \\
(\mathbf{m} / \mathbf{s})\end{array}$ & $\begin{array}{c}\text { Drop Angle } \\
\text { (above horizontal) }\end{array}$ & $\begin{array}{c}\text { Altitude } \\
(\mathbf{m})\end{array}$ & $\begin{array}{c}\text { Impact Speed } \\
(\mathbf{m} / \mathbf{s})\end{array}$ & $\begin{array}{c}\text { Impact } \\
\text { Angle }\end{array}$ & $\begin{array}{c}\text { Distance } \\
(\mathbf{m})\end{array}$ \\
\hline $\mathbf{2 5}$ & 0 & 180 & 63.61 & 69.16 & 244 \\
$\mathbf{5 0}$ & 0 & 180 & 70.92 & 56.95 & 367 \\
$\mathbf{7 5}$ & 0 & 180 & 76.41 & 51.08 & 469 \\
\hline 50 & $\mathbf{- 1 5}$ & 180 & 71.52 & 56.29 & 301 \\
50 & $\mathbf{0}$ & 180 & 70.92 & 56.95 & 367 \\
50 & $\mathbf{1 5}$ & 180 & 71.35 & 60.52 & 421 \\
\hline 50 & 0 & $\mathbf{1 8 0}$ & 70.92 & 56.95 & 367 \\
50 & 0 & $\mathbf{3 0 0}$ & 85.04 & 64.59 & 463 \\
50 & 0 & $\mathbf{5 0 0}$ & 104.90 & 71.00 & 581 \\
\hline
\end{tabular}

Table 4. Trajectory and impact angle for the ammunition with spherically blunted tangent ogive nose cone

\begin{tabular}{cccccc}
\hline $\begin{array}{c}\text { Aircraft Speed } \\
(\mathbf{m} / \mathbf{s})\end{array}$ & $\begin{array}{c}\text { Drop Angle } \\
\text { (above horizontal) }\end{array}$ & $\begin{array}{c}\text { Altitude } \\
(\mathbf{m})\end{array}$ & $\begin{array}{c}\text { Impact Speed } \\
(\mathbf{m} / \mathbf{s})\end{array}$ & $\begin{array}{c}\text { Impact } \\
\text { Angle }\end{array}$ & $\begin{array}{c}\text { Distance } \\
(\mathbf{m})\end{array}$ \\
\hline $\mathbf{2 5}$ & 0 & 180 & 63.49 & 69.15 & 251 \\
$\mathbf{5 0}$ & 0 & 180 & 84.83 & 64.61 & 471 \\
$\mathbf{7 5}$ & 0 & 180 & 105.70 & 51.00 & 474 \\
\hline 50 & $\mathbf{1 5}$ & 180 & 71.53 & 56.40 & 296 \\
50 & $\mathbf{0}$ & 180 & 70.77 & 56.97 & 360 \\
50 & $\mathbf{1 5}$ & 180 & 71.10 & 60.50 & 412 \\
\hline 50 & 0 & $\mathbf{1 8 0}$ & 70.77 & 56.97 & 360 \\
50 & 0 & $\mathbf{3 0 0}$ & 84.83 & 64.61 & 471 \\
50 & 0 & $\mathbf{5 0 0}$ & 104.86 & 71.08 & 570 \\
\hline
\end{tabular}

Table 5. Trajectory and impact angle for the ammunition with truncated tangent ogive nose cone

\begin{tabular}{cccccc}
\hline \hline $\begin{array}{c}\text { Aircraft Speed } \\
(\mathbf{m} / \mathbf{s})\end{array}$ & $\begin{array}{c}\text { Drop Angle } \\
(\text { above horizontal })\end{array}$ & $\begin{array}{c}\text { Altitude } \\
(\mathbf{m})\end{array}$ & $\begin{array}{c}\text { Impact Speed } \\
(\mathbf{m} / \mathbf{s})\end{array}$ & $\begin{array}{c}\text { Impact } \\
\text { Angle }\end{array}$ & $\begin{array}{c}\text { Distance } \\
(\mathbf{m})\end{array}$ \\
\hline $\mathbf{2 5}$ & 0 & 180 & 63.33 & 56.40 & 217 \\
$\mathbf{5 0}$ & 0 & 180 & 70.11 & 57.69 & 337 \\
$\mathbf{7 5}$ & 0 & 180 & 74.54 & 52.65 & 433 \\
\hline 50 & $\mathbf{- 1 5}$ & 180 & 70.92 & 56.92 & 278 \\
50 & $\mathbf{0}$ & 180 & 70.11 & 57.69 & 337 \\
50 & $\mathbf{1 5}$ & 180 & 70.58 & 61.40 & 383 \\
\hline 50 & 0 & $\mathbf{1 8 0}$ & 70.11 & 57.69 & 337 \\
50 & 0 & $\mathbf{3 0 0}$ & 84.52 & 65.50 & 424 \\
50 & 0 & $\mathbf{5 0 0}$ & 104.11 & 71.78 & 528 \\
\hline
\end{tabular}

Table 6. The results of one-way analysis of variance for impact angle versus nose cone type

\begin{tabular}{|c|c|c|c|c|c|}
\hline Source & DF & Adj SS & Adj MS & F- Value & P- Value \\
\hline Nose Cone Type & 2 & 10.31 & 5.153 & 0.13 & 0.879 \\
\hline Error & 24 & 956.41 & 39.850 & - & - \\
\hline Total & 26 & 966.72 & - & - & - \\
\hline
\end{tabular}

Table 7. The results of one-way analysis of variance for impact speed versus nose cone type

\begin{tabular}{|c|c|c|c|c|c|}
\hline Source & DF & Adj SS & Adj MS & F-Value & P-Value \\
\hline Nose Cone Type & 2 & 159.1 & 79.56 & 0.45 & 0.645 \\
\hline Error & 24 & 4282.7 & 178.45 & - & - \\
\hline Total & 26 & 4441.9 & - & - & - \\
\hline
\end{tabular}




\section{CONCLUSIONS}

Smart fire extinguishing ammunition (SFEA) is a new and effective product we have designed for use in aerial firefighting. This product was called smart fire extinguishing ammunition, taking into account several electronic equipment and software that make the product autonomous. The effects of different nose cone designs on the trajectory and impact angle of the SFEA were investigated. Three different types of nose cones, namely spherically blunted conic, spherically blunted tangent ogive and truncated tangent ogive type nose cones were studied. The following findings were obtained in the study:

(a) The drag coefficient was found to be 0.136 for the spherically blunted conic nose cone, 0.138 for the spherically blunted tangent ogive nose cone, and 0.154 for the truncated tangent ogive nose cone.

(b) The drag coefficients for the spherically blunted conic nose cone and the spherically blunted tangent ogive nose cone are very close to each other, while the drag coefficient for the truncated tangent ogive nose cone is slightly higher $(+11.76 \%)$.

(c) The higher coefficient of drag in the truncated tangential ogive nose cone is due to the deterioration of the flow structure and the formation of a separation zone. This causes the pressure drag to increase.

(d) The one-way analysis of variance (ANOVA) showed that the nose cone difference did not have a significant effect on the impact speed, impact angle and horizontal distance of the ammunition at the investigated speeds and altitudes.

(e) Flame detection, distance measurement and impact sensors, which should be in the smart fire extinguishing ammunition, should be on the plane at the front of the ammunition and in contact with the external environment. To place these sensors in the nose cone, a truncated tangent ogive nose cone was chosen as the nose cone for the SFEA.

\section{Acknowledgments}

The design proposed in this study participated in the 2242 University Students Research Project Competitions organized by TÜBITTAK Scientist Support Programs in the category of Defense, Space and Aviation, and won the Second Prize in Turkey in the Final Competition held between 17-22 September 2019. A patent application was made to the Turkish Patent and Trademark Office for the design. We would like to thank the Rectorate of Inönü University for their support for the patent application.

\section{REFERENCES}

[1] Çengel, Y. A. (2015). Heat Transfer $5^{\text {th }}$ ed., McGraw Hill, New York.

[2] Gudmundsson, S. (2014). Aircraft Drag Analysis (Chapter 15), General Aviation Aircraft Design, ButterworthHeinemann, p.661-760

[3] White, M., F. (2010). "Fluid Mechanics," Section 7.1 (7th edition)

[4] Schlichting, H. 1960. Boundary Layer Theory, McGraw-Hill New York.

[5] Subha, R., Drozario, A. M., Sreeshin, M. (2020). Study on Various Types of Nose Cone Profiles at Supersonic Speed through Analytical, Experimental and Numerical Simulation Methods, Journal of Xidian University. 14. 10.37896/jxu14.6/312. VOLUME 14, ISSUE 6, 2020. 2651-2675.

[6] Iyer, A. R., Pant, A. (2020). A Review On Nose Cone Designs for Different Flight Regimes, International Research Journal of Engineering and Technology (IRJET), Volume: 07 Issue: 08, 3546-3554. 
[7] GICHD. (2017). Characterization of explosive weapons study, annex E - Mk 82 aircraft bomb, Geneva International Centre for Humanitarian Demining, Geneva, Switzerland.

[8] Crowell S., Gary A. (1996). The descriptive geometry of nose cones, https://web.archive.org/web/20110411143013/http://www.if.sc.usp.br/ projetosulfos/artigos/NoseCone_EQN2.P DF Retrieved: 24.04.2021.

[9] ANSYS, Inc. (2011). Ansys Fluent 14.0: Theory Guide, 275 Technology Drive Canonsburg, PA 15317.

[10] Gurney, R. W. (1943). The Initial Velocities of Fragments from Bombs, Shells and Grenades, BRL-405. Ballistic Research Laboratory, Aberdeen, Maryland. USA.

[11] United Nations Office for Disarmament Affairs. (2015). International Ammunition Technical Guideline (2nd ed.). New York, NY: United Nations Headquarters.

[12] Watts, A., Curtis S., Braswll J., Underwood M. (2014). Missile Design Tool (MDT) User's Guide, Commander, U.S. Army Research, Development, and Engineering Command, Redstone Arsenal. 